\title{
POLA KOMUNIKASI INTERPERSONAL KORBAN TRAFFICKING PENGANTIN PESANAN DI SINGKAWANG KALIMANTAN BARAT
}

\author{
Elly Triana \\ PT. HUTCP CHISON CP Telecomunication 3 Yogyakarta \\ Jln. C. Simanjuntak $1 \& 3$ Yogyakarta \\ e-mail:ellytriana@gmail.com \\ Christina Rochayanti / Isbandi \\ Jurusan Ilmu Komunikasi FISIP UPN "Veteran" Yogyakarta \\ Jl. Babarsari No. 2 Tambakbayan Yogyakarta, Telp. (0274) 485268 \\ e-mail : christinarochayanti@yahoo.com
}

\begin{abstract}
Trafficking is slavery activity of including in human being commerce, one of the typical modus which during the time trend in Kalbar, that is "order bride". The brokers look for the beautiful women in Singkawang Town, especially amoy-amoy to be married with the foreign citizen men, Taiwan, Hongkong, and Singapore. Amount of informan is five people. Research method used by descriptive qualitative, this method giving description and communications analyse between individual in relation between perpetrator of order bride with the brokers/ middleman. Accumulation data technique used by Observation, Interview, and reference study technique for the perception, obtaining information, and collect the data, adding data, supporting data from other sources. The results of this research indicated that pattern of interpersonal communications in relation of order brige with the brokers/middleman done by approach every order bridge started with the introduction, continued with the dating, dating intensity, and communications of one-way, two-way, feedback, and persuasive. All this represent the important matter in making and looking after good cooperation or relation.
\end{abstract}

Key words: interpersonal communications, perception, persuasive

\section{Pendahulan}

Trafficking yang terjadi di Kalimantan Barat semakin marak terjadi, hal ini diketahui dari data-data yang diperoleh di lembaga-lembaga yang ada di Indonesia. Di antaranya dari International Organization for Migration (IOM). Lembaga tersebut mengungkapkan kasus perdagangan orang, perempuan dan anak yang terjadi di Kalimantan barat periode Juni 2005-Oktober 2006 sebanyak 1.231 kasus, di mana presentase korban terbesar 80,89 persen berasal dari daerah itu sendiri. Data lain, berasal dari shelter Aisyiyah Kalbar. Yayasan Anak Bangsa yang berkedudukan di Entikong mencatat dari sepanjang tahun 2008 yang berjumlah 449 kasus, 160 kasus dari
Januari hingga awal Juni tahun 2009. Di tahun 2009, setiap warga Indonesia diperdagangkan ke Malaysia dengan harga 2.600 ringgit Malaysia atau setara dengan Rp 7,5 juta (Koran Republika, Minggu, 07 juni 2009). Sementara data dari Kepolisian Daerah Kalimantan Barat, terdapat 21 kasus pada tahun 2005, 35 kasus tahun 2006 dan pada Tahun 2008 mencapai 36 kasus. Meliputi kasus penipuan, pemalsuan surat-surat, perkosaan, memperkerjakan anak di bawah umur, komersialisasi perempuan untuk industri seks, dan lainnya. Ini hanyalah sebagian kecil dari hasil pengumpulan data yang dilakukan $\mathrm{CiBa}$. Lembaga tersebut juga mencatat data dari Pengadilan Negeri Pontianak, dimana pada tahun 2004 terdapat satu kasus, dan 
tahun 2006 terdapat 11 kasus. Sementara data dari Kejaksaan Negeri Pontianak, pada tahun 2006 terdapat 14 kasus. Sedangkan data dari Yayasan Lembaga Bantuan Hukum Perempuan Indonesia untuk Keadilan (LBH APIK), yang dikutip dari liputan media lokal pada tahun 2006 ada 25 kasus dan hingga Maret 2007 baru ditemukan 1 kasus. Adapun jenis kasus, meliputi, penculikan, penjualan bayi, penjualan perempuan untuk pelacuran, dan penjualan amoy (sebutan bagi perempuan Tionghoa) untuk pengantin pesanan. Data dari rumah sakit Dr Soedarso Pontianak, pada tahun 2005-2006 terdapat 17 kasus, dua kasus lain terjadi di tahun 2007. Sementara ANTARAmencatat, pada tahun 2007 ini telah ada dua perempuan yang melapor ke polisi dalam kasus pengantin pesanan tujuan Taiwan.

Salah satu modus khas yang selama ini sedang trend di Kalbar, yaitu "pengantin pesanan". Para calo mencari wanita-wanita cantik di Kota Singkawang, terutama amoy-amoy untuk dikawinkan dengan laki-laki warga negara asing, Taiwan, Hongkong, dan Singapura. Akibat kawin pesanan itu, tidak sedikit kaum perempuan yang menjadi terlantar di negara lain dan tertipu, sesampai disana dipekerjakan sebagai penjaja seks komersil (PSK) ataupun lainnya (www.google. com//trafficking Kalbar, Yayasan pemberdayaan pefor nusantara Pontianak).

Kota Singkawang, Kalimantan Barat terkenal dengan julukan Kota Seribu Kuil. Tapi, kota yang mayoritas dihuni etnis Tionghoa ini juga memiliki budaya kawin foto atau pengantin pesanan dari Singkawang. Budaya ini biasanya dialami para amoy, sebutan bagi wanita Tionghoa, yang menikah dengan pria asal Taiwan. Saat ini, hampir 30 ribu amoy di Taiwan. Mereka sudah tak peduli lagi pendidikan. Tercatat presentase anak sekolah tidak tamat SD di Singkawang mencapai 35,91 persen. Sementara data Komisi Nasional Perlindungan Anak mencatat perdagangan manusia mencapai 12 ribu kasus. "Sebagian besar mereka berangkat secara ilegal dengan pemalsuan dokumen, ancaman, jeratan utang, penipuan," kata Rosita, aktivis dari Lembaga Bantuan Hukum Peka (YNI/Anastasya Putri dan Erwin Arief, September 2007). Nasib para amoy Singkawang yang terjebak dalam budaya "kawin foto" atau pengantin pesanan. Secara manusiawi, fenomena ini memang termasuk gejala anomali sosial. Tapi sepertinya jadi persoalan yang rumit, karena berkaitan dengan persoalan ekonomi, yang mau atau tidak, mereka harus tetap bisa bertahan hidup di tengah gempuran nilai materialisme dan hedonisme.

\section{Pendekatan Psikologi Sosial}

Sebuah teori psikologi sosial tentang pengembangan hubungan antara manusia yang berkaitan dengan komunikasi interpersonal. Komunikasi yang terjadi antara perempuan pengantin pesanan dengan calo/makelar termasuk jenis komunikasi interpersonal mengingat individu yang terlibat dalam komunikasi tersebut langsung bertemu muka, bahkan hati ke hati. Komunikasi interpersonal merupakan bagian dari kehidupan manusia yang cukup berarti dalam pemenuhan kebutuhan sosial manusia. Melalui komunikasi yang efektif setiap individu mempunyai lebih banyak kesempatan untuk menjalin hubungan interpersonal yang baik. Teori self disclosure, setiap orang bisa mengetahui tentang dirinya, maupun orang lain. Teori ini menggunakan konsep Johari Window (jendela Johari) yang melukiskan bahwa dalam pengembangan hubungan antara seseorang dengan lainnya yang mana memungkinkan terwakili melalui suasana jendela Johari yang diwakili dengan keempat bidang (jendela) tersebut yaitu :

Gambar 1 Jendela Johari tentang bidang pengenalan diri dan orang lain

\begin{tabular}{l|l|l} 
Kita ketahui & Tidak kita ketahui & \\
\hline Terbuka & Buta & Publik \\
\hline Tersembunyi & Tidak dikenal & Privat
\end{tabular}

Penjelasan dari gambar 1 yaitu (a) bidang satu melukiskan suatu kondisi di mana antara seseorang dengan orang lain mengembangkan suatu hubungan yang terbuka sehingga kedua pohak saling mengetahuimasalah tentang hubungan mereka, disebut juga area terbuka (Open area); (b) bidang dua melukiskan suatu kondisi masalah tentang hubungan antara kedua pihak hanya 
diketahui orang lain namun tidak diketahui diri sendiri, disebut area buta (Blind area); (c) bidang tiga : melukiskan suatu kondisi masalah tentang hubungan antara kedua pihak yang hanya diketahui diri sendiri namun tidak diketahui orang lain, disebut juga area tersembunyi (Hidden area); (d) bidang empat melukiskan suatu kondisi masalah di mana kedua pihak sama-sama tidak mengetahui, disebut juga area tidak dikenal (Unknown area).

Makin luas diri publik seseorang, makin terbuka seseorang pada orang lain, makin akrab hubungan seseorang dengan orang lain. Makin baik seseorang mengetahui orang lain, makin akrab hubungan dengan orang lain, makin lebar daerah terbuka jendela seseorang untuk mendapat informasi dan berinteraksi (Rahmat, 2003:108). Dalam hal ini melihat bahwa perempuan pengantin pesanan yang terjadi di Singkawang dapat mempunyai pandangan dan kenalan luas, mengetahui orang lain, akrab dengan banyak hubungan antara keluarga calon pasangan di luar negeri. kemudian pengantin pesanan yang mempunyai daya komunikasi yang baik, maka akan diterima dengan baik oleh calo/makelar dan keluarga calon pasangan dengan kemampuan komunikasi tersebut.

\section{Teori Simetri Newcomb}

Menurut pakar psikologi sosial Thedore M. Newcomb (1953), dalam teori Simetri diungkapkan bahwa kita berusaha saling mempengaruhi satu sama lain untuk menghasilkan simetri (atau keseimbangan atau ekuilibrium). Newcomb mengemukakan bahwa upaya-upaya untuk mempengaruhi orang lain adalah sebuah fungsi daya tarik seseorang bagi orang lain. Dalam hal ini teori Newcomb lebih merupakan sebuah teori daya tarik antar individu. Apabila kita gagal mencapai simetri melalui komunikasi dengan orang lain tentang sebuah objek yang penting bagi kita, maka kita kemudian dapat mengubah sikap kita terhadap orang penting bagi kita, maka kita kemudian dapat mengubah sikap kita terhadap orang itu maupun pada objek yang diperbincangkan guna menciptakan simetri (Werner J.Severin \& James W.Tankard,Jr, 2005:157).

Pada kehidupan korban pengantin pesanan, calo melakukan komunikasi interper- sonal untuk menghasilkan keseimbangan/simetri dengan mempengaruhi dan merubah pikiran calon korban pengantin pesanan untuk melakukan kawin kontrak.

Pada penelitian ini hubungan antara teori Simetri Newcomb dengan trafficking adalah dalam teori simetri diungkapkan bahwa kita berusaha saling mempengaruhi satu sama lain untuk menghasilkan simetri (atau keseimbangan atau ekuilibrium). Newcomb mengemukakan bahwa upaya-upaya untuk mempengaruhi orang lain adalah sebuah fungsi daya tarik seseorang bagi orang lain.

Trafficking dalam modus pengantin pesanan terjadi akibat calo berhasil menciptakan simetri/keseimbangan sehingga para calon korban dapat dipengaruhi dengan komunikasi dalam teori simetri sehingga korban bersedia melakukan kawin kontrak.

\section{Metode Penelitian}

Penulis menggunakan penelitian deskriptif kualitatif yang cenderung mengarahkan kajiannya pada perilaku manusia sehari-hari dalam keadaannya yang rutin secara apa adanya (Sutopo, 2002: 34). Kualitas suatu penelitian ditentukan oleh ketetapan dalam pemilihan metode penelitian, dimana metode tersebut dapat dipergunakan untuk menangkap dan menjelaskan realitas sosial secara jelas sesuai dengan karakter objek studi yang di teliti.

Penulis menggunkan metode penelitian deskriptif yaitu penelitian yang memaparkan situasi atau peristiwa dengan tidak menjelaskan hubungan dan menguji hipotesis atau membuat prediksi. Penggunaan data disampaikan secara verbal dan klasifikasinya bersifat teoritis. Data yang diambil tidak diolah melaluiperhitungan sistematis maupun dengan rumus statistik. Penelitian deskriptif bertujuan menggambarkan secara sistematik dan akurat fakta dan karakteristik mengenai populasi atau mengenai bidang tertentu serta menggambarkan situasi atau kejadian.

Data yang dikumpulkan semata-mata bersifat deskriptif sehingga tidak bermaksud penjelasan, menguji, membuat prediksi, maupun mempelajari implikasi (Azwar, 2003:7). Topik pada penelitian ini adalah komunikasi interpersonal 
pada korban trafficking pengantin pesanan di Singkawang Kalimantan Barat.

\section{Hasil Penelitian dan Pembahasan}

Berdasarkan penelitian penulis menemukan bahwa penyebab terjadinya trafficking (perdagangan manusia) dalam modus pengantin pesanan di Singkawang Kalimantan Barat adalah dipicu oleh kemiskinan dan tidak tersedianya lapangan pekerjaan, sehingga para perempuan yang tinggal di Singkawang melakukan kawin kontrak untuk mengubah taraf hidup mereka. Faktor berikutnya adalah tingkat pendidikan yang rendah sehingga seringkali mereka terpaksa menerima pekerjaan yang bersifat eksploratif, faktor kemiskinan ini disebabkan oleh pola pikir orangtua China di Singkawang Kalimantan Barat bahwa sekolah tinggi-tinggi itu tidak penting, yang penting sudah bisa baca dan menghitung. Sekolah tinggitinggi hanya menghabiskan waktu dan uang saja, lebih baik membantu orangtua berdagang atau membuka usaha dagang saja. Pola pikir seperti ini membuat orang-orang keturunan China di Singkawang tidak memiliki pendidikan yang tinggi dan tidak dapat bekerja dikantoran dan tidak bisa mengubah taraf hidup mereka. Faktor lainnya adalah tingkat konsumerisme, para perempuan di Singkawang ingin memiliki barang mewah dan bagus, supaya diakui dilingkungan mereka, dan faktor yang terakhir adalah kesamaan etnis, orangtua mereka mendoktrin anak-anak mereka dengan mengatakan bahwa orang-orang keturunan Tionghua di Singkawang satu keturunan dengan orang-orang Taiwan, ini dilakukan orangtua agar anak-anak mereka tidak merasa dijual oleh orangtua mereka. Kondisi demikian ini dimanfaatkan oleh para calo/perantara perkawianan sebagai sasaran bagi calo-calo pemburu calon pengantin perempuan untuk menjaring korbannya dengan mudah dengan tujuan untuk mendapatkan keuntungan berupa uang. Pola komunikasi yang terjadi antara pengantin pesanan dengan calo/ makelar di Singkawang Kalimantan Barat adalah komunikasi interpersonal yang bersifat dua arah/ sirkuler dan satu terjadi dengan baik sehingga informasi yang diberikan calo/makelar kepada pelaku pengantin pesanan dapat dengan mudah diterima oleh pelaku pengantin pesanan tanpa noise/gangguan. Jadi bentuk komunikasi interpersonal yang bersifat dua arah dan satu arah merupakan bentuk yang efektif untuk mempengaruhi calon korban pengantin pesanan untuk melakukan kawin kontrak. Bila dikaitakan dengan teori bahwa komunikasi yang dipergunakan manusia berkomunikasi maupun berhubungan dengan orang lain bentuk dan macamnya beraneka ragam. Salah satu yang paling sering dipergunakan dalam berkomunikasi setiap hari adalah komunikasi interpersoanal. Komunikasi yang baik akan mampu mengarahkan terjadinya komunikasi interpersonal yang lebih akrab antara satu individu atau kelompok lain. Komunikasi yang baik pula dapat meminimalisir kecurigaan-kecurigaan yang terjadi dalam hubungan masyarakat.

Melihat kawin kontrak semakin marak terjadi di wilayah Singkawang Kalimantan Barat pemerintah daerah kota Singkawang kurang perduli tentang trafficking yang bermodus kawin kontrak ini. Dapat dilihat pada dua periode pada pergantian menteri pemberdayaan perempuan. Pada tahun 2001 menteri Negara pemberdayaan perempuan Sri Redjeki Sumaryono menyatakan: pihaknya sedang mengupayakan bagaimana mengatasi masalah yang dihadapi oleh para perempuan di daerah tersebut, terutama yang melakukan kawin kontrak dengan warga asing. Jadi memang, sangat rumit sekali permasalahan mengenai kawin kontrak di sana (Senin, 10 Desember 2001, 15.07 Wib)

Kemudian pada tahun 2008 menteri pemberdayaan perempuan Meutia Hatta mengatakan: Menteri Negara Pemberdayaan Perempuan, Meutia Hatta mengatakan, umumnya trafficking terjadi karena faktor kemiskinan. Remaja-remaja perempuan yang mengalami trafficking biasanya dimanfaatkan sebagai tulang punggung keluarganya yang miskin (Kompas, Jumat, 14 April, $13.48 \mathrm{wib})$

Pernyataan ini juga diperkuat dengan pernyataan dari Kepala Dinas Pariwisata Kota Singkawang, Istri Handayani yang mengatakan bahwa: 
Mengenai amoy Singkawang yang cantik dan sebagian besar modis ini, sejak dulu banyak yang terlibat "kawin kontrak" dengan pria asal Taiwan atau Hong Kong. Dia menuturkan, jika di pedalaman Singkawang ada rumah bagus terselip di antara rumah-rumah sederhana beratap ilalang, pastilah ada anggota keluarga di rumah itu yang kawin kontrak dengan pria asal Taiwan atau Hong Kong" (Januari 2009).

Diharapkan pemerintah daerah Singkawang membuat program untuk pemberantasan trafficking yang bermodus kawin kontrak. Pemerintah Daerah hanya menggunakan pasal 297 KUHP untuk menangani trafficking yang terjadi, pemerintah daerah kurang peduli tentang trafficking yang bermodus kawin kontrak yang terjadi di Singkawang Kalbar. Hal ini ditambahkan dengan pernyataan dariLBH-PIK Pontianak, Hairiah yang mengatakan bahwa (Mon, 11 Apr 2005):

Berharap adanya Peraturan Daerah yang mengatur masalah ini, terutama untuk antisipasi trafficking, mengingat kondisi Kalbar yang rentan, terutama terhadap masalah koordinasi penanganan kasus trafficking perempuan dan anak di wilayah Kalimantan Barat. Saat ini pihaknya menjadi lembaga inisiator dalam pembuatan rencana dan memfasilitasi multistakeholder dalam rangka gerakan anti trafficking (http://www.jurnalperempuan. com/ Kalbar Perlu Perda Untuk Tangani Kasus Trafficking).

Data ini juga ditambahkan dengan pernyataan dari Robert Lay Thu, 15 Dec 2005 05:33:42 -0800 yang mengatakan:

Melalui wakil komunitas Tionghua yang ada di DPRD Singkawang harus memperjuangkan pemerintah daerah membuat regulasi yang bersifat melindungi warganya (amoi). Seperti peraturan: Semua jodoh yang beroperasi daerah ini harus terdaftar (dengan begini ada standar peraturan para agent harus lakukan sesuai prosedur hukum. Misal ada surat karater cek bagi pelamar,dll (http://www.undoc. org/unodc/ en/trafficking links.html).

Bila dikaitkan secara teoritis pada kelima kasus ini para calo/makelar menggunakan komunikasi interpersonal yang bersifat persuasif dan dengan model sirkuler/ bersifat dua arah dan satu arah. Seperti model Gerbner (1956) merupakan perluasan dari model Laswell. Model ini terdiri dari model verbal dan model dramatic. Model verbal Gerbner adalah sebagai berikut Seseorang (sumber, komunikator) mempersepsi suatu kejadian dan bereaksi dalam suatu situasi melalui suatu alat (saluran: media, rekayasa fisik: fasilitas administratif dan kelembagaan untuk distribusi dan kontrol) untuk menyediakan materi dalam suatu bentuk dan konteks yang mengandung isi dan yang mempunyai suatu konsekuensi. Jadi model Gerbner menunjukkan bahwa seseorang mempersepsi suatu kejadian dan bereaksi dalam suatu situasi mengirimkan pesan kepada suatu transmitter yang pada gilirannya mengirimkan sinyal kepada penerima (receiver).

Secara teoritis komunikasi interpersonal adalah komunikasi yang terjadi antara individu satu dengan yang lain, biasanya terjadi dialog dan biasanya terjadi antara individu satu dengan yang lain, biasanya terjadi dialog dan biasanya sacara lisan. Pengertian komunikasi saling menatap (tatap muka) sehingga terjadi kontak pribadi (personal contact). Jenis komunikasi interpersonal ini dianggap paling efektif untuk mengubah sikap, pendapat, dan perilaku. Komunikasi interpersonal adalah komunikasi yang terjadi antara individu satu dengan individu yang lain, biasanya terjadi dialog dan biasanya terjadi antara individu satu dengan yang lain, biasanya terjadi dialog dan biasanya secara lisan. Pengertian komunikasi saling menatap (tatap muka) sehingga terjadi kontak pribadi (personal contact). Jenis komunikasi interpersonal ini dianggap paling efektif untuk mengubah sikap, pendapat, dan perilaku. Komunikasi jenis ini adalah komunikasi yang efektif untuk mengubah sikap seseorang karena sifatnya yang dialogis berupa percakapan. Arus balik bersifat langsung dan komuniktor bisa mengetahui tanggapan komunikasi ketika itu juga, sewaktu komunikasi dilakukan Sunarjo (1991:93). Komunikasi interpersonal adalah komunikasi yang pernyataannya 
disampaikan secara langsung oleh komunikator kepada komunikan, namun ada juga yang isi pernyataannya disampaikan oleh komunikator melalui alat perantara atau medium (Soehoet, 2002:54). Lain dari pada itu Joseph A.Devito (1997:231) mende-finisikan komunikasi interpersonal sebagai proses pengiriman dan penerimaan pesan-pesan antara dua orang atau kelompok kecil orang-orang dengan beberapa efek umpan balik seketika. Trenholm dan Jensen (1995:26) mendefinisikan komunikasi interpersonal sebagai komunikasi antara dua orang yang berlangsung secara tatap muka. Nama lain dari komunikasi ini adalah diadik (dyadic). Komunikasi diadik biasanya bersifat spontan dan informal (Wiryanto, 2004:33). Komunikasi yang seperti ini terjadi pada hubungan pelaku pengantin pesanan dengan calo/ makelar demi untuk mencapai tujuan mereka yaitu keuntungan dari modus trafficking ini.

Berdasarkan hasil dari penelitian yang dilakukan di kota Singkawang Kalimantan Barat dapat dikatakan bahwa bentuk komunikasi interpersonal yang bersifat dua arah/sirkuler dan satu terjadi dengan baik sehingga informasi yang diberikan calo/makelar kepada pelaku pengantin pesanan dapat dengan mudah diterima oleh pelaku pengantin pesanan tanpa noise/gangguan. Jadi bentuk komunikasi interpersonal yang bersifat dua arah dan satu arah merupakan bentuk yang efektif untuk mempengaruhi calon korban pengantin pesanan untuk melakukan kawin kontrak. Komunikasi yang baik sangat menunjang keberhasilan proses interaksi antarmanusia, dengan terciptanya komunikasi yang baik antara pelaku pengantin pesanan dengan calo/makelar. Pesan yang disampaikan oleh calo/makelar dapat diterima dengan baik oleh para pelaku pengantin pesanan melalui komunikasi yang baik karena komunikasi merupakan suatu umpan balik dan respon yang mengetahui seberapa baik komunikasi itu terjadi, berhasil atau tidaknya komunikasi tersebut.

Komunikasi yang baik bukanlah hal yang mudah untuk dilakukan, keterbukaan antarindividu yang berlatar belakang beda budaya merupakan cara yang baik agar dapat saling mengenal, memudahkan komunikasi. Dalam hubungannya dengan manusia sebagai makhluk sosial, terkandung suatu maksud bahwa manusia bagaimanapun juga tidak dapat terlepas dari individu yang lain. Secara kodrati manusia akan selalu hidup bersama. Hidup bersama antar manusia akan berlangsung dalam berbagai bentuk komunikasi dan situasi yang mempengaruhinya. Melakukan komunikasi merupakan bagian terpenting dari semua aktivitas, agar timbul pengertian.

Komunikasi merupakan proses penyampaian ide, pemikiran, pendapat dan berita ke suatu tempat tujuan serta menimbulkan reaksi umpan balik. Komunikasi adalah jembatan yang bisa menyatukan dua hati dan dua pikiran. Komunikasi yang baik harus bersifat dua arah, tidak ada yang terlalu banyak bicara dan tidak ada yang terlalu banyak diam. Komunikasi yang baik tidak hanya sekedar bicara, tapi juga mendengar dengan telinga dan hati. Komunikasi yang terbuka akan membuat hubungan lebih akrab, dapat mencegah kesalahpahaman dan memudahkan penyelesaian konflik.

Dari hasil penelitian dapat dilihat bahwa pola komunikasi yang dilakukan oleh calo/makelar kepada korban pengantin pesanan berjalan dengan baik. Calo/makelar dapat dengan mudah mempengaruhi korban pengantin pesanan walawupun cerita-cerita atau kisah yang pernah terjadi pada perempuan yang menjadi pengantin pesanan banyak yang ditipu dan disiksa. Hubungan antara korban pengantin pesanan dengan calo/makelar mempunyai arti penting. Mereka saling bekerja sama dan saling memberikan informasi. Pelaku pengantin pesanan banyak mendapatkan informasi tentang kawin kontrak dari calo/makelar untuk menjadi bekal selama pelaku pengantin pesanan dalam masa kontrak. Oleh karena itu untuk memperjelas pembahasan mengenai hubungan antara korban pengantin pesanan dengan calo/makelar, maka dibuatlah diagram yang mekanisme kawin kontrak yang berdasarkan hasil penelitian.

Dari beberapa narasumber, sebagian besar dari mereka berpendidikan sangat rendah sehingga dengan mudah dipengaruhi oleh calo/makelar dengan menggunakan komunikasi interpersonal. Berdasarkan uraian tentang semua hasil penelitian mengenai hubungan pendidikan dengan kasus trafficking didukung dengan kutipan sebagai berikut:

Anak perempuan (Warga Negara Indonesia) WNI etnis China terutama dari keluarga 
miskin kurang mendapatkan akses pendidikan yang lebih tinggi sehingga sulit mendapatkan akses sumberdaya ekonomi karena kurang memiliki akses untuk mendapatkan peluang kerja. Akibatnya anak perempuan dianggap hanya akan manusia sebagai tindak pidana, telah diatur dalam KUHP yaitu dalam pasal 297. Menurut ketentuan pasal 297 memperniagakan perempuan dan memperniagakan laki-laki yang belum dewasa, dihukum penjara selama-lamaya enam tahun. Istilah "traf-

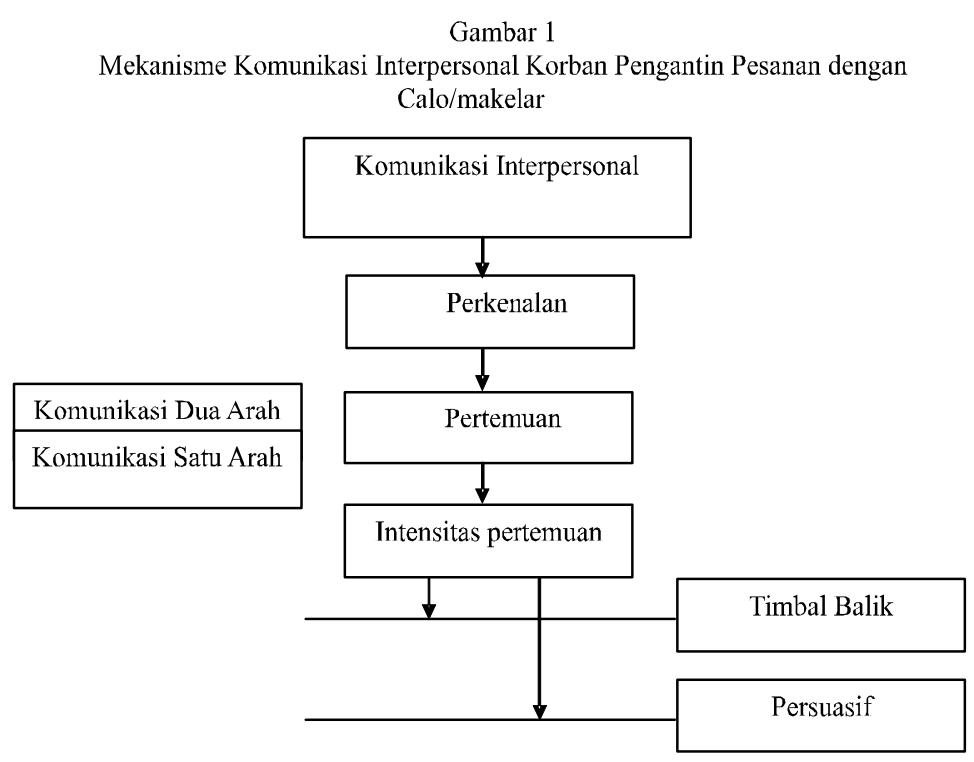

membebani keluarga miskin, di sisi lain anak perempuan tersebut juga ingin keluar dari kemiskinan dan dapat hidup lebih layak. Kondisi demikian ini dimanfaatkan oleh para calo/perantara perkawinan sebagai sasaran bagi calo-calo pemburu calon pengantin perempuan untuk menjaring korbannya dengan mudah(trafficking mail border.com).

Pengertian perdagangan orang menurut Undang-undang Nomor 21 tahun 2007 tentang pemberantasan tindak pidana perdagangan orang adalah tindakan perekrutan, pengangkutan, penampungan, pengiriman, pemindahan, atau penerimaan seseorang dengan ancaman kekerasan, penggunaan kekerasan, penculikan, penyekapan, pemalsuan, penipuan penyalahgunaan kekuasaan atau posisi rentan, penjeratan utang atau memberi bayaran atau manfaat, sehingga memperoleh persetujuan dari orang yang memegang kendali atas orang lain tersebut, baik yang dilakukan didalam Negara maupun antar Negara, untuk tujuan eksploitasi atau mengakibatkan orang tereksploitasi. Sedangkan pengertian tindak pidana perdagangan orang menurut undang-undang ini adalah setiap tindakan atau serangkaian tindakan yang memenuhi unsur-unsur tindak pidana yang ditentukan dalam undang-undang ini. Perdagangan ficking in human" sebagai kejahatan yang mengacu pada instrument international memiliki pengertian yang lebih luas dari pada ketentuan perdagangan manusia sebagaimana yang diatur dalam pasal 297 KUHP tersebut, sebab trafficking (perdagangan manusia) mencakup perbuatan perekrutan orang yang diperdagangkan. Di samping itu, tindakan tersebut dilakukan dengan maksud untuk melakukan eksploitasi terhadap manusia. Oleh karena itu, ketentuan pasal 297 KUHP disebut sebagai tindak pidana trafficking (perdagangan manusia) dalam arti sempit, sedangkan instrument internasional tentang trafficking disebut tindak pidana trafficking dalam arti luas.

Pada rancangan undang-undang Republik Indonesia tentang pemberantasan tindak pidana perdagangan orang dengan Rahmat Tuhan yang Maha Esa Presiden Republik Indonesia seperti yang berikut yaitu (a) pasal 1, nomor 6 tentang Eks-ploitasi adalah tindakan baik dengan atau tanpa persetujuan korban yang meliputi tetapi tidak terbatas pada pelacuran, kerja atau pelayanan paksa, perbudakan atau praktik serupa perbudakan, pemindahan atau transplantasi organ dan atau jaringan tubuh, atau segala tindakan yang 
berupa penindasan, pemerasan dan pemanfaatan fisik, seksual, tenaga, dan atau kemampuan seseorang oleh pihak lain dengan secara sewenangwenang untuk mendapatkan keuntungan baik materiil maupun immaterial; (b) pasal 2, tentang Pemberantasan tindak pidana perdagangan orang dalam Undang-undang ini merupakan kebijakan dan langkah-langkah strategis untuk mencegah, menindak dan menghukum pelaku tindak pidana perdagangan orang, serta melindungi korban dengan tetap menjunjung tinggi hukum dan hak asasi manusia; (c) pasal 4, tentang Dipidana, karena melakukan tindak pidana perdagangan orang,dengan pidana penjara paling singkat 4 (empat) tahun dan paling lama 15 (lima belas) tahun dan pidana denda paling sedikit Rp. 100.000. 000,00 (seratus juta rupiah) dan paling banyak $\mathrm{Rp}$. 300.000.000,00 (tiga ratus juta rupiah), setiap orang yang dengan sengaja memasukkan orang ke Indonesia dengan maksud :Diperdagangkan di wilayah negara Republik Indonesia; atau dibawa lagi ke luar wilayah Indonesia untuk diperdagangkan ke wilayah negara lain.

Pengawasan pemerintah/kepolisian sudah ketat dan sering tertangkap jadi calo/makelar banyak yang berhenti karena tidak mau masuk penjara, begitu juga masalah pelaku tindak pidana dan denda membuat korban takut untuk melapor karena korban merasa dia juga melakukan semua ini dengan persetujuan orangtua dan kesediaan diri sehingga membuatnya tidak mau berurusan dengan pihak polisi. Untuk melakukan wawancara saja peneliti mengalami kesulitan, banyak yang tidak mau menceritakan kisah kawin kontraknya karena Kalimantan Barat sedang gencar melakukan kasus trafficking.

Penelitian ini merupakan kelanjutan dari penelitian sebelumnya dalam beberapa bidang jurusan. (1) dalam ilmu komunikasi yang berjudul "Pesan Moral dalam Film Memoirs Of A Geisha" oleh Novi Farida Priyadi. (2) dalam ilmu Hubungan International berjudul "Kebijakan pemerintah Indonesia terhadap perdagangan perempuan dan anak" oleh Mohammad Johan Fathoni. (3) kemudian dari ilmu Hukum berjudul "Penegakan hukum tindak pidana perdagangan perempuan (Trafficking) di kota Singkawang provinsi Kalimantan Barat" oleh Syarifahlia Malini
Sary.

Dalam penelitian sebelumnya pada judul (1) membahas trafficking yang dilakukan oleh orangtua karena kemiskinan yang terjadi di Jepang; Pada judul (2) lebih fokus pada kebijakan pemerintah Indonesia terhadap perdagangan perempuan dan anak adalah di Indonesia perdagangan manusia yang kebanyakan dari korbannya adalah wanita; Pada judul (3) lebih membahas jika perkawinan itu mempunyai kejanggalan maka aparat tidak segan-segan untuk menindak tegas. Pada kesempatan ini penulis lebih memfokuskan pada pola komunikasi interpersonal pada korban pengantin pesanan di Singkawang Kalimantan Barat.

Efektifitas yang dilakukan oleh calo/ makelar terhadap mempersuasif calon korban pengantin pesanan berhasil dengan baik karena korban pengantin pesanan tidak dapat berpikir, mereka hanya memikirkan keuntungan, membalas budi, merubah nasib, diakui di lingkungan, menyerah karena pendidikan yang dimilikinya, dan membantu calo/makelar, dari profesi kawin kontrak.

\section{Simpulan}

Berdasarkan hasil penelitian dan pembahasan, maka dapat disimpulkan bahwa penyebab terjadinya trafficking (perdagangan manusia) dalam modus pengantin pesanan di Singkawang Kalimantan Barat adalah dipicu oleh kemiskinan dan tidak tersedianya lapangan pekerjaan, sehingga para perempuan yang tinggal di Singkawang melakukan kawin kontrak untuk merubah taraf hidup mereka. Faktor berikutnya adalah tingkat pendidikan yang rendah, ini disebabkan oleh pola pikir orangtua mereka bahwa tidak penting sekolah tinggi-tinggi hanya menghabiskan waktu dan uang saja sehingga seringkali mereka terpaksa menerima pekerjaan yang bersifat eksploratif, faktor lainnya adalah tingkat konsumerisme, para perempuan di Singkawang ingin memiliki barang mewah dan bagus untuk sehingga mereka diakui dilingkungan mereka, dan faktor yang terakhir adalah kesamaan etnis, orangtua mereka mendoktrin anak-anak mereka dengan mengatakan bahwa orang-orang keturunan Tionghua di Singkawang satu keturunan dengan orang-orang Taiwan, ini dilakukan orang- 
tua agar anak-anak mereka tidak merasa kalau mereka dijual oleh orangtua mereka. Kondisi demikian ini dimanfaatkan oleh para calo/perantara perkawianan sebagai sasaran bagi calo-calo pemburu calon pengantin perempuan untuk menjaring korbannya dengan mudah dengan tujuan untuk mendapatkan keuntungan berupa uang.

Bentuk komunikasi yang terjadi antara pengantin pesanan dengan calo/makelar di Singkawang Kalimantan Barat adalah komunikasi interpersonal yang bersifat dua arah/sirkuler dan satu arah, feedback, persuasif terjadi dengan baik sehingga informasi yang diberikan calo/makelar kepada pelaku pengantin pesanan dapat dengan mudah diterima oleh pelaku pengantin pesanan tanpa noise/gangguan. Jadi bentuk komunikasi interpersonal yang bersifat dua arah, satu arah, feedback, persuasif merupakan bentuk yang efektif untuk mempengaruhi calon korban pengantin pesanan untuk melakukan kawin kontrak.

\section{Daftar Pustaka}

De Vito, Joseph, 1996, Komunikasi Antar Manusia, Professional Books, Jakarta.

Mulyana, Dedy, 2001, Ilmu Komunikasi Suatu Pengantar, Remaja Rosdakarya, Bandung.
Soehoet, A.M.Hoeta, 2002, Teori komunikasi 2, IISIP, Jakarta.

Sutopo, H.B, 2002, Metodelogi Penelitian Kualitatif, PT.Grafindo Persada.

Wiryanto, 2004, Pengantar Ilmu Komunikasi, Grasindo, Jakarta.

\section{Website:}

http://www.google.com/Koran Republika, Minggu, 07 Juni 2009

http://www.google.com/trafficking Kalbar, yayasan pemberdayaan pefor nusantara Pontianak

http://www.google.com/YNI, September 2007 http://www.google.com/teori simetri Newcomb http://www.google.com/teori Jendela Johari http://www.Kompas, Jumat, 14 April 2001 Jam 15.07 Wib

http://www.trafficking mail border.com http://www.google.com/trafficking LBH-PIK, Senin, 11 April 2005

http://www.google.com/trafficking dalam modus kawin kontrak, Senin, 10 Desember 2001

http://www.google.com/kawin kontrak, Januari 2009

hhtp://www.undoc.org/unodc/en/trafficking links.hmtl 